\title{
Pemanfaatan program CSR perusahaan untuk pemberdayaan perekonomian masyarakat Kabupaten Pelalawan di masa pandemi Covid-19
}

\author{
Andrew Shandy Utama* \\ Universitas Andalas \\ * andrew.fh.unilak@gmail.com
}

\begin{abstract}
Abstrak. Pandemi Covid-19 yang melanda Provinsi Riau berdampak terhadap perekonomian masyarakat, termasuk masyarakat Desa Palas. Selain mengharapkan bantuan dana dari pemerintah, salah satu peluang yang dapat dimanfaatkan oleh masyarakat Desa Palas untuk membangun perekonomian desa adalah memanfaatkan program CSR dari perusahaan-perusahaan yang beroperasi di Kabupaten Pelalawan. Pengabdian kepada masyarakat ini bertujuan untuk menjelaskan pemanfaatan program CSR perusahaan untuk pemberdayaan perekonomian masyarakat di masa pandemi Covid-19. Metode pelaksanaan yang digunakan dalam kegiatan pengabdian kepada masyarakat ini menggunakan metode ceramah disertai dialog secara langsung dengan masyarakat. Berdasarkan Pasal 74 UndangUndang Nomor 40 Tahun 2007 tentang Perseroan Terbatas ditegaskan bahwa perusahaan yang menjalankan kegiatan usahanya di bidang sumber daya alam dan/atau bidang yang berkaitan dengan sumber daya alam wajib melaksanakan CSR. Program CSR PT RAPP yang dapat dimanfaatkan oleh masyarakat Desa Palas untuk membangun perekonomiannya yaitu program Integrated Farming System dan program UMKM. Sebelum diberikan penyuluhan hukum, hanya 17,5\% dari 20 orang peserta yang mengetahui hukum mengenai CSR. Setelah diberikan penyuluhan hukum, terjadi peningkatan menjadi $75 \%$ dari 20 orang peserta yang menjawab dengan benar. Artinya, kegiatan pengabdian kepada masyarakat ini telah berhasil meningkatkan pemahaman masyarakat Desa Palas.
\end{abstract}

Kata kunci: CSR, perekonomian, pandemi Covid-19

\begin{abstract}
The Covid-19 pandemic that hit Riau Province had an impact on the economy of the community, including the people of Palas Village. Apart from expecting financial assistance from the government, one of the opportunities that the Palas Village community can take advantage of to develop the village economy is to take advantage of the CSR programs of companies operating in Pelalawan Regency. This community service aims to explain the use of the company's CSR program to empower the community's economy during the Covid-19 pandemic. The method of implementation used in community service activities uses the lecture method accompanied by direct dialogue with the community. Based on Article 74 of Law Number 40 of 2007 concerning Limited Liability Companies, it is stated that companies that carry out their business activities in the field of natural resources and / or fields related to natural resources are required to carry out CSR. The CSR program of PT RAPP that can be used by the people of Palas Village to build their economy is the Integrated Farming System program and the UMKM program. Before being given legal counseling, only $17.5 \%$ of the 20 participants knew the law regarding CSR. After being given legal education, there was an increase to $75 \%$ of the 20 participants who answered correctly. This means that this community service activity has succeeded in increasing the understanding of the Palas Village community.
\end{abstract}

Keywords: CSR, economy, Covid-19 pandemic

To cite this article: Utama, A.S. 2020. Pemanfaatan program CSR perusahaan untuk pemberdayaan perekonomian masyarakat Kabupaten Pelalawan di masa pandemi Covid-19. Unri Conference Series: Community Engagement 2: 77-83. https://doi.org/10.31258/unricsce.2.77-83

(C) 2020 Authors

Peer-review under responsibility of the organizing committee of Seminar Nasional Pemberdayaan Masyarakat 2020 


\section{PENDAHULUAN}

Salah satu tujuan negara adalah untuk meningkatkan kesejahteraan rakyat. Hal ini sebagaimana yang ditegaskan dalam Pembukaan Undang-Undang Dasar Negara Republik Indonesia Tahun 1945 yang menyatakan bahwa terdapat empat tujuan dari didirikannya Indonesia sebagai sebuah negara, yaitu melindungi segenap bangsa Indonesia dan seluruh tumpah darah Indonesia; memajukan kesejahteraan umum; mencerdaskan kehidupan bangsa; serta ikut melaksanakan ketertiban dunia yang berdasarkan kemerdekaan, perdamaian abadi, dan keadilan sosial (Utama \& Rizana, 2018).

Pembangunan nasional yang selama ini dilaksanakan oleh pemerintah lebih banyak berpusat di kota-kota besar saja. Infrastruktur dan fasilitas umum yang dibangun di kota terasa sangat lengkap untuk menunjang kehidupan masyarakat mulai dari infrastruktur jalan dan jembatan yang megah, fasilitas pendidikan yang berkualitas, fasilitas kesehatan yang modern, jaringan listrik yang menyala 24 jam, transportasi umum yang nyaman, hingga jaringan internet yang sudah menjadi kebutuhan primer bagi masyarakat perkotaan. Ironisnya, ternyata masih banyak dijumpai daerah-daerah yang belum tersentuh pembangunan, terutama di pedesaan. Jangankan menikmati jaringan internet, bahkan masih ada desa yang sama sekali belum ada jaringan listrik.

Untuk membangun desa, sejak tahun 2015 pemerintah telah menyalurkan 'Dana Desa' sebesar lebih kurang 187 triliun rupiah dari Anggaran Pendapatan dan Belanja Negara (APBN). Dana tersebut sebagian besar ternyata digunakan untuk membangun infrastruktur desa, sehingga hanya sebagian kecil yang digunakan untuk membangun perekonomian masyarakat. Akibatnya, pada saat pandemi Covid-19 melanda, masyarakat mengalami krisis.

Berdasarkan data dari Badan Pusat Statistik Kabupaten Pelalawan tahun 2015 disebutkan bahwa 12\% masyarakat Kabupaten Pelalawan masuk kategori masyarakat miskin, dengan jumlah 44.127 jiwa. Jumlah tersebut menjadikan Kabupaten Pelalawan sebagai daerah dengan jumlah masyarakat miskin yang terbanyak kedua di Provinsi Riau. Hal ini tentunya sangat bertolak belakang dengan kekayaan alam yang dimilikinya serta jumlah perusahaan besar yang beroperasi di Kabupaten Pelalawan.

Salah satu perusahaan besar berskala nasional yang beroperasi di Kabupaten Pelalawan adalah PT Riau Andalan Pulp \& Paper (disingkat RAPP) yang berkedudukan di Kecamatan Pangkalan Kerinci. Data dari Badan PMPPT Kabupaten Pelalawan menyebutkan bahwa nilai investasi dari RAPP mencapai lebih kurang 26 triliun rupiah. Dengan nilai investasi yang besar tersebut, keberadaan RAPP seharusnya mampu meningkatkan kesejahteraan masyarakat Kabupaten Pelalawan.

Dalam rangka meningkatkan kesejahteraan masyarakat, selain mempekerjakan tenaga kerja lokal, sebenarnya RAPP telah menyiapkan program Corporate Social Responsibility (CSR) sebagai wujud kepedulian dari perusahaan terhadap masyarakat Kabupaten Pelalawan. Adapun CSR yang diprogramkan oleh RAPP ada 6 (enam), yaitu: 1) Integrated Farming System; 2) Usaha Mikro, Kecil, dan Menengah; 3) Social Infrastructure; 4) Education; 5) Vocational Training; dan 6) Employee Volunteerism. Meskipun demikian, dari hasil wawancara dengan Kepala Desa Palas diketahui bahwa masyarakat Desa Palas tidak mengetahui mengenai bentuk-bentuk program CSR dari perusahaan karena selama ini masyarakat meminta bantuan dana dari perusahaan hanya untuk memeriahkan acara 17 Agustus saja.

Dari latar belakang permasalahan yang telah digambarkan di atas, maka penulis tertarik untuk memberikan penyuluhan hukum kepada masyarakat Kabupaten Pelalawan mengenai pemanfaatan program CSR perusahaan untuk pemberdayaan perekonomian masyarakat di masa pandemi Covid-19.

\section{METODE PENERAPAN}

Metode pelaksanaan yang digunakan dalam kegiatan pengabdian kepada masyarakat ini menggunakan metode ceramah disertai dialog secara langsung dengan masyarakat Kabupaten Pelalawan, khususnya masyarakat Desa Palas Kecamatan Pangkalan Kuras, yang sebagian besar bekerja sebagai buruh perkebunan dan pabrik kelapa sawit di Kabupaten Pelalawan. Untuk mengukur tingkat pemahaman peserta, tim pengabdi membagikan kuisioner yang berisi 4 (empat) pertanyaan kepada peserta sebelum penyuluhan hukum dimulai lalu meminta para peserta untuk mengisi kuisioner tersebut dan mengumpulkannya kepada tim pengabdi. Setelah penyuluhan hukum selesai, tim pengabdi kembali membagikan kuisioner yang sama kepada para peserta untuk diisi dan dikumpulkan kembali kepada tim pengabdi. 


\section{HASIL DAN KETERCAPAIAN SASARAN}

Covid-19 merupakan sebuah virus yang awalnya mewabah di Kota Wuhan, Tiongkok. Covid-19 kemudian menyebar ke berbagai penjuru dunia, termasuk Indonesia. Dalam rangka mencegah penyebaran Covid-19, pemerintah mengeluarkan kebijakan untuk menutup tempat-tempat yang berpotensi menjadi tempat berkumpulnya banyak orang, seperti objek wisata, mall, sekolah, dan lain sebagainya. Akibatnya, perekonomian masyarakat menurun drastis. Dampak dari pandemi Covid-19 tidak hanya terjadi di perkotaan, tetapi juga dirasakan oleh masyarakat di pedesaan.

Desa adalah kesatuan masyarakat hukum yang memiliki batas wilayah, yang berwenang untuk mengatur dan mengurus urusan pemerintahannya, kepentingan masyarakat setempat berdasarkan prakarsa masyarakat, hak asal-usulnya, dan/atau hak tradisional yang diakui dan dihormati dalam sistem pemerintahan di Indonesia. Dasar hukum yang mengatur mengenai desa adalah Undang-Undang Nomor 6 Tahun 2014 tentang Desa (Fahrial, Utama, \& Dewi, 2019). Desa Palas merupakan salah satu desa di Kecamatan Pangkalan Kuras Kabupaten Pelalawan yang membentang di sepanjang Jalan Lintas Sorek. Masyarakat Desa Palas sebagian besar bekerja sebagai buruh pada perkebunan dan pabrik kelapa sawit yang ada di Kabupaten Pelalawan.

Pada bulan September 2020, Provinsi Riau masuk dalam kategori 10 (sepuluh) besar daerah yang paling banyak terpapar Covid-19. Pandemi Covid-19 yang melanda Provinsi Riau berdampak terhadap perekonomian masyarakat, termasuk masyarakat Desa Palas. Selain mengharapkan bantuan dana dari pemerintah, salah satu peluang yang dapat dimanfaatkan oleh masyarakat Desa Palas untuk membangun perekonomian desa adalah memanfaatkan program CSR dari perusahaan-perusahaan yang beroperasi di Kabupaten Pelalawan, baik perusahaan swasta maupun Badan Usaha Milik Negara (BUMN) dan Badan Usaha Milik Daerah (BUMD).

Sebelum memberikan penyuluhan hukum, tim pengabdi terlebih dahulu membagikan kuisioner yang berisi 4 (empat) pertanyaan kepada para peserta dengan rincian sebagai berikut:

Tabel 1. Kuisioner Sebelum Penyuluhan Hukum

\begin{tabular}{|c|c|c|c|}
\hline \multirow{2}{*}{ NO. } & \multirow{2}{*}{ DAFTAR PERTANYAAN } & \multicolumn{2}{|c|}{ JAWABAN } \\
\hline & & BENAR & SALAH \\
\hline 1 & Apa itu CSR? & 9 & 11 \\
\hline 2 & Apa saja bentuk-bentuk program CSR? & 5 & 15 \\
\hline 3 & Apa dasar hukum yang mengatur CSR di Provinsi Riau? & - & 20 \\
\hline 4 & Apa sanksi bagi perusahaan yang tidak melaksanakan CSR? & - & 20 \\
\hline & Persentase & $17,5 \%$ & $82,5 \%$ \\
\hline
\end{tabular}

Perusahaan adalah badan hukum yang merupakan persekutuan modal, didirikan berdasarkan perjanjian, melakukan kegiatan usaha dengan modal dasar yang seluruhnya terbagi dalam saham, dan memenuhi persyaratan yang ditetapkan oleh Undang-Undang Nomor 40 Tahun 2007 tentang Perseroan Terbatas dan peraturan pelaksanaannya (Adjie, 2008). Tujuan utama dari sebuah perusahaan adalah untuk mencari keuntungan yang sebesar-besarnya. Hal ini merupakan tanggung jawab para pengurus perusahaan kepada pemegang saham sebagai pemilik dari perusahaan tersebut. Inilah dasar filosofis didirikannya sebuah perusahaan. Namun, kegiatan operasional perusahaan dalam rangka memaksimalisasi keuntungannya seringkali merugikan masyarakat, terutama masyarakat yang bertempat tinggal di sekitar lokasi perusahaan (Fahmi, 2015).

Menurut perspektif hukum bisnis, terdapat dua tanggung jawab yang harus diimplementasikan dalam etika bisnis, yaitu tanggung jawab hukum dan tanggung jawab sosial. Tanggung jawab hukum meliputi aspek perdata dan aspek pidana, sedangkan tanggung jawab sosial berarti bahwa perusahaan bukan hanya merupakan entitas bisnis yang mencari keuntungan saja, melainkan merupakan satu kesatuan dengan keadaan sosial, ekonomi, dan lingkungan tempat perusahaan tersebut beroperasi.

Berdasarkan Pasal 74 Undang-Undang Nomor 40 Tahun 2007 tentang Perseroan Terbatas ditegaskan bahwa perusahaan yang menjalankan kegiatan usahanya di bidang sumber daya alam dan/atau bidang yang berkaitan dengan sumber daya alam wajib melaksanakan CSR. Faktanya, menurut data dari Badan Pusat Statistik Kabupaten Pelalawan tahun 2015 disebutkan bahwa 12\% masyarakat Kabupaten Pelalawan masuk kategori masyarakat miskin, dengan jumlah 44.127 jiwa. Jumlah tersebut menjadikan Kabupaten Pelalawan 
sebagai daerah dengan jumlah masyarakat miskin yang terbanyak kedua di Provinsi Riau. Hal ini tentunya sangat bertolak belakang dengan banyaknya jumlah perusahaan besar yang beroperasi di Kabupaten Pelalawan.

Lahirnya Peraturan Daerah Provinsi Riau Nomor 6 Tahun 2012 tentang Tang gung Jawab Sosial Perusahaan di Provinsi Riau semakin memperkokoh dasar hukum mengenai pelaksanaan program CSR dari perusahaanperusahaan yang ada di Provinsi Riau (Utama, 2018).

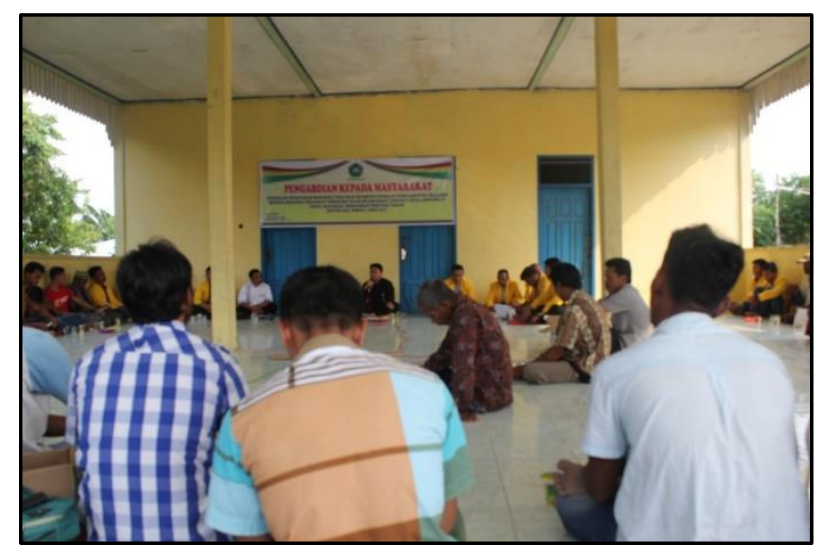

Gambar 1. Foto Kegiatan Penyuluhan Hukum di Desa Palas

Peraturan Daerah Provinsi Riau Nomor 6 Tahun 2012 tentang Tanggung Jawab Sosial Perusahaan di Provinsi Riau mengatur bahwa perusahaan berkewajiban untuk:

1. Menyusun rancangan penyelenggaraan program CSR sesuai dengan prinsip-prinsip tanggung jawab sosial dunia usaha dengan memperhatikan kebijakan pemerintah daerah dan peraturan perundang-undangan.

2. Menumbuhkan dan mengembangkan sistem jejaring kerja sama dan kemitraan dengan pihak-pihak lain serta melaksanakan kajian, monitoring, dan evaluasi terhadap pelaksanaan program CSR dengan memperhatikan kepentingan perusahaan, pemerintah daerah, masyarakat, dan kelestarian lingkungan.

3. Menetapkan komitmen bahwa program CSR merupakan bagian yang tidak terpisahkan dalam kebijakan manajemen perusahaan maupun program pengembangan perusahaan di dalam peraturan perusahaan.

4. Menerima usulan dari masyarakat, baik perorangan maupun kelompok yang sesuai dengan kebutuhan masyarakat.

Berdasarkan Pasal 10 Peraturan Daerah Provinsi Riau Nomor 6 Tahun 2012 tentang Tanggung Jawab Sosial Perusahaan di Provinsi Riau diatur bahwa program CSR dapat berbentuk program pemberdayaan masyarakat, program kemitraan, program bina lingkungan, program investasi, program promosi, serta program sumbangan/donasi. Selanjutnya, pada Pasal 11 Peraturan Daerah Provinsi Riau Nomor 6 Tahun 2012 tentang Tanggung Jawab Sosial Perusahaan di Provinsi Riau disebutkan bahwa bidang kerja CSR dapat dijalankan pada:

1. Bidang pendidikan

2. Bidang kesehatan

3. Bidang infrastruktur

4. Bidang olahraga dan seni budaya

5. Bidang sosial dan keagamaan

6. Bidang pelestarian lingkungan hidup

7. Bidang usaha ekonomi kerakyatan

8. Bidang pemberdayaan masyarakat adat

9. Bidang kerja lainnya yang secara nyata memberikan dampak peningkatan kualitas masyarakat.

Keberhasilan suatu daerah dalam meningkatkan kesejahteraan masyarakatnya dapat terwujud apabila seluruh komponen masyarakat ikut dilibatkan, termasuk partisipasi yang nyata dari perusahaan yang beroperasi di daerah tersebut (Untung, 2009).

Dalam rangka memberdayakan perekonomian masyarakat, Kepala Desa Palas dapat memanfaatkan program CSR dari perusahaan-perusahaan besar yang beroperasi di Kabupaten Pelalawan (Hasnati \& Utama, 2020). 
Perusahaan terbesar yang ada di Kabupaten Pelalawan adalah RAPP. RAPP bergerak di bidang industri kertas dan sejenisnya. RAPP berkedudukan di Kecamatan Pangkalan Kerinci, yang letaknya tidak terlalu jauh dari Desa Palas karena Kecamatan Pangkalan Kerinci bersebelahan dengan Kecamatan Pangkalan Kuras.

Adapun CSR yang diprogramkan oleh RAPP ada 6 (enam), yaitu: 1) Integrated Farming System; 2) Usaha Mikro, Kecil, dan Menengah; 3) Social Infrastructure; 4) Education; 5) Vocational Training; dan 6) Employee Volunteerism. Dari keenam program tersebut, terdapat 2 (dua) program CSR yang dapat dimanfaatkan oleh masyarakat Desa Palas untuk membangun perekonomiannya, yaitu (Utama, 2018):

1. Program Integrated Farming System (IFS)

Program IFS adalah program pemberian bantuan berupa bibit tanaman dan buah-buahan kepada kelompok masyarakat yang berwirausaha di bidang pertanian dan perkebunan serta pemberian bantuan berupa bibit ikan kepada kelompok masyarakat yang berwirausaha di bidang perikanan.

2. Program Usaha Mikro, Kecil, dan Menengah (UMKM)

Program UMKM adalah program pemberian bantuan dana kepada masyarakat yang berwirausaha, baik usaha yang inline dengan bidang usaha perusahaan seperti menjual pupuk tanaman maupun usaha yang offline dengan bidang usaha perusahaan seperti menjual makanan khas daerah.

Berdasarkan Pasal 32 Peraturan Daerah Provinsi Riau Nomor 6 Tahun 2012 tentang Tanggung Jawab Sosial Perusahaan di Provinsi Riau ditegaskan bahwa perusahaan yang tidak melaksanakan CSR dapat dikenakan sanksi administratif berupa peringatan tertulis dan bentuk-bentuk sanksi lainnya sesuai dengan peraturan perundang-undangan, yaitu pembatasan kegiatan usaha, pembekuan kegiatan usaha, dan pencabutan kegiatan usaha.

Tabel 2. Kuisioner Sebelum Penyuluhan Hukum

\begin{tabular}{|c|c|c|c|}
\hline \multirow{2}{*}{ NO. } & \multirow{2}{*}{ DAFTAR PERTANYAAN } & \multicolumn{2}{|c|}{ JAWABAN } \\
\hline & & BENAR & SALAH \\
\hline 1 & Apa itu CSR? & 19 & 1 \\
\hline 2 & Apa saja bentuk-bentuk program CSR? & 16 & 4 \\
\hline 3 & Apa dasar hukum yang mengatur CSR di Provinsi Riau? & 11 & 9 \\
\hline 4 & Apa sanksi bagi perusahaan yang tidak melaksanakan CSR? & 14 & 6 \\
\hline & Persentase & $75 \%$ & $25 \%$ \\
\hline
\end{tabular}

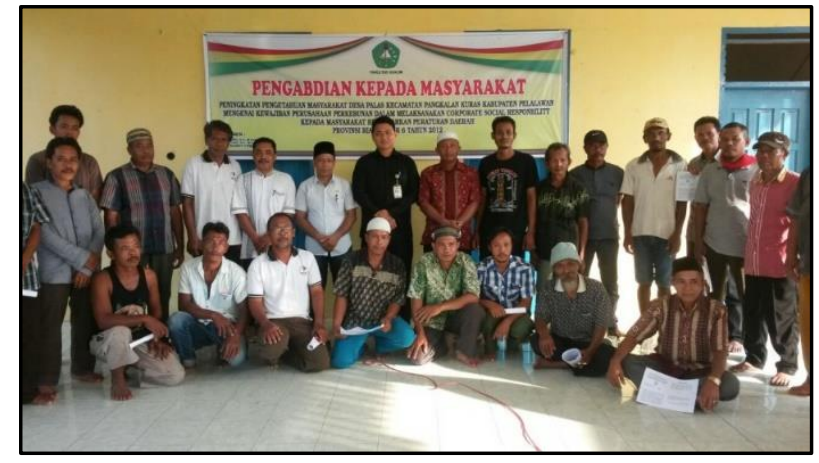

Gambar 2. Foto Bersama Setelah Kegiatan Penyuluhan Hukum

Sebelum diberikan penyuluhan hukum, dari 20 orang peserta, hanya $17,5 \%$ peserta yang menjawab dengan benar dengan rincian pertanyaan nomor 1 ada 9 orang dan pertanyaan nomor 2 ada 5 orang, sedangkan 82,5\% jawabannya salah. Setelah diberikan penyuluhan hukum, dari 20 orang peserta, terjadi peningkatan menjadi $75 \%$ peserta berhasil menjawab dengan benar dan sisanya $25 \%$ jawabannya salah. Artinya, kegiatan pengabdian kepada masyarakat ini dapat dikatakan telah berhasil meningkatkan pemahaman hukum mengenai CSR kepada masyarakat Desa Palas.

Program CSR sebenarnya bukan hanya bermanfaat bagi masyarakat, melainkan juga bermanfaat untuk membentuk citra perusahaan apabila dikemas dengan publikasi yang tepat. 


\section{KESIMPULAN}

Pandemi Covid-19 yang melanda Provinsi Riau berdampak terhadap perekonomian masyarakat, termasuk masyarakat Desa Palas. Selain mengharapkan bantuan dana dari pemerintah, salah satu peluang yang dapat dimanfaatkan oleh masyarakat Desa Palas untuk membangun perekonomian desa adalah memanfaatkan program CSR dari perusahaan-perusahaan yang beroperasi di Kabupaten Pelalawan. Program CSR RAPP yang dapat dimanfaatkan oleh masyarakat Desa Palas untuk membangun perekonomiannya yaitu program Integrated Farming System (IFS) dan program Usaha Mikro, Kecil, dan Menengah (UMKM). Sebelum diberikan penyuluhan hukum, hanya $17,5 \%$ dari 20 orang peserta yang mengetahui hukum mengenai CSR. Setelah diberikan penyuluhan hukum, terjadi peningkatan menjadi $75 \%$ dari 20 orang peserta yang menjawab dengan benar. Artinya, kegiatan pengabdian kepada masyarakat ini telah berhasil meningkatkan pemahaman masyarakat Desa Palas.

\section{DAFTAR PUSTAKA}

Adjie, A. 2008. Status Badan Hukum, Prinsip-prinsip, dan Tanggung Jawab Sosial Perseroan Terbatas. Bandung: Mandar Maju.

Fahmi. 2015. Pergeseran Tanggung Jawab Sosial Perseroan; Dari Tanggung Jawab Moral ke Tanggung Jawab Hukum. Yogyakarta: FH UII Press.

Fahrial, Utama, A. S., dan Dewi, S. 2019. Pemanfaatan Corporate Social Responsibility (CSR) terhadap Pembangunan Perekonomian Desa. Jurnal Wawasan Yuridika, 3(2), 259-272.

Fahrial, Fatriani, R., dan Utama, A. S. 2020. Utilization of Corporate Social and Environmental Responsibility to Improve Community Economy in Pekanbaru City. Proceeding of International Conference ICE-Tech, 469, 1-5.

Hasnati and Utama, A. S. 2020. Implementation of Corporate Social Responsibility (CSR) by Forestry and Plantation Companies in Pelalawan Regency, Riau Province, Indonesia. Journal of Law and Political Sciences, 25(4), 309332.

Suhendro, Utama, A. S., dan Susanty, A. P. 2019. Pelaksanaan CSR PT Asia Forestama Raya terhadap Peningkatan Perekonomian Masyarakat Berdasarkan Peraturan Daerah Provinsi Riau Nomor 6 Tahun 2012. Jurnal Ensiklopedia Social Review, 1(2), 140-144.

Suhendro dan Utama, A. S. 2019. Implementation of Corporate Social Responsibility by PT Asia Forestama Raya in Rumbai Pesisir District of Pekanbaru City Based on Regional Regulation of Riau Province 6 of 2012. Russian Journal of Agricultural and Socio-Economic Sciences, 9(93), 274-284.

Untung, H. B. 2009. Corporate Social Responsibility. Jakarta: Sinar Grafika.

Utama, A. S. dan Rizana. 2017. Implementasi Corporate Social Responsibility PT Riau Crumb Rubber Factory terhadap Masyarakat Kelurahan Sri Meranti Kota Pekanbaru. Jurnal Novelty, 8(2), 173-186.

Utama, A. S. 2018. Implementasi Corporate Social Responsibility PT Riau Andalan Pulp \& Paper terhadap Masyarakat di Kabupaten Pelalawan. Jurnal Selat, 5(2), 123-133.

Utama, A. S. dan Rizana. 2018. Penegakan Hukum terhadap Pelaksanaan Tanggung Jawab Sosial Perusahaan di Kecamatan Rumbai Pekanbaru. Jurnal Equitable, 3(1), 1-11.

Utama, A. S. dan Rizana. 2018. Upaya Hukum Masyarakat Kecamatan Rumbai Pekanbaru dalam Pemenuhan Hak Masyarakat Melalui Program Corporate Social Responsibility (CSR). Jurnal Melayunesia Law, 2(1), 79-93.

Utama, A. S. 2018. The Implementation of Corporate Social Responsibility (CSR) PT Riau Crumb Rubber Factory to the Community of Sri Meranti Village in Pekanbaru. Proceeding of International Conference Icon-ITSD, 175, 16.

Utama, A. S. 2018. Pelaksanaan Tanggung Jawab Sosial dan Lingkungan Perusahaan Berdasarkan Undang-Undang Nomor 40 Tahun 2007 untuk Meningkatkan Kesejahteraan Masyarakat Kecamatan Rumbai Pesisir Kota Pekanbaru. Jurnal Cendekia Hukum, IV(1), 26-36.

Utama, A. S. dan Rizana. 2018. Pelaksanaan Corporate Social Responsibility dalam Rangka Optimalisasi Pelestarian Lingkungan. Jurnal Litigasi, 19 (2), 127-147.

Utama, A. S. 2018. Problematika dalam Pelaksanaan Tanggung Jawab Sosial Perusahaan Kehutanan dan Perkebunan di Kabupaten Pelalawan Provinsi Riau. Supremasi Jurnal Hukum, 1(2), 67-80. 
Utama, A. S., Rizana, dan Putra, T. A. 2019. Tanggung Jawab Sosial Perusahaan PT Asia Forestama Raya di Kota Pekanbaru dan Penegakan Hukumnya. Pagaruyuang Law Journal, 2(2), 148-162. 